\title{
EFFECTS OF MINERAL OIL-DIESEL FUEL BLENDS ON EXHAUST EMISSIONS IN A DIESEL ENGINE
}

\section{Hasan BAYINDIR}

\author{
Dicle University, Vocational School of Technical Sciences, \\ Machinery and Metal Technologies Department \\ 21280 Diyarbakır/Turkey \\ hbayindir@dicle.edu.tr
}

Received: 1 November 2016; Accepted: 29 December 2016

\begin{abstract}
Mainly dating from the midst of the year 2007, various items have been sold in tins for using in diesel vehicles instead of diesel fuel; including viscous base oil at first, with the name of Oil-NO: 10. There is strong evidence that these types of nonstandard fuels have been still utilized with the various names at diesel engines in our country.

In this study, by using diesel fuel and mineral oil (SAE10W and SAE5W) at various rates-mixtures of diesel fuel, exhaust emissions in a diesel engine were experimentally analyzed. When engine speed increased, changes in values of exhaust emissions were determined with the relevant mixtures at various rates. The experiments were carried out with a single-cylinder, direct injection, air cooled diesel engine under various speed and various load conditions. When these fuels compared to diesel fuel, they did not show any important differences from diesel fuel in terms of engine performance. When compared the fuel mixtures to the D2 fuel, the CO, NOx and SOx values were high, the UHC (unburned hydrocarbon) emissions were partly low for mixture fuels. This showed have significantly negative effects on environmental pollution.
\end{abstract}

Key Words: Diesel Engine, Diesel Fuel, SAE10W, SAE5W, Exhaust Emissions, Nonstandard oil

\section{INTRODUCTION}

From past to present, there has been an increase in need of energy resources all around the world. This situation has driven researchers and users to investigate different energy sources. Towards these developments, it has been predicted that current petroleum-derived fuels will be depleted in the near future. When the historical development of energy need in the world was analyzed, production and consumption shifted from solid fuels to liquid and gaseous fuels, now the share of hard coal lignite reduced from $80 \%$ to $31 \%$. On the other hand, the rate of petroleum arose from $14 \%$ to $38 \%$, this also motivated people to search for alternative resources [1]. 
The methyl ester fuel was produced from inedible animal fat and used in a single-cylinder and direct injection diesel engine. It was suggested that the methyl ester of animal fat could be used as fuel within the normal ambient temperature in summer without any problems but it would be suitable to use an agent reducing the freezing point under the cold weather conditions or use it in mixture with the diesel [2].

Also, the methyl ester of animal fat did not show any significant changes in engine performance and its exhaust emissions were found to be low.

Researchers tested $100 \%$ sunflower methyl ester and 50\% sunflower methyl ester - 50\% diesel fuel mixtures in a diesel engine. According to the test results, engine torque and power got down; specific fuel consumption increased when the methyl ester and the mixture were used as fuels. They reported that there were decreases in CO emissions, increases in NOx emissions due to $100 \%$ sunflower methyl ester and 50\% sunflower methyl ester $-\% 50$ diesel fuel [3]. The methyl ester of canola oil and standard diesel fuel mixtures could be used as alternative fuels in a diesel engine. When the methyl ester of canola oil added to the diesel fuel increased, there were decreases in engine power, engine torque, $\mathrm{CO}$ and $\mathrm{HC}$ emissions, increases in specific brake fuel consumption, NOx emissions and smoke density [4]. Oil- NO: 10 was a type of mineral oil having low viscosity (high fluid property), with mainly total annual consumption of 10.000-15.000 ton/years. Owing to the technical features of these mineral oils, these mineral oils started to be used as diesel fuels because they could be mixed with diesel fuel, directly used as fuels in some vehicles and were below the taxable market prices of diesel fuel. In particular, this practice started with using and selling oils with low viscosity known as spindle or light neutral for these aims and was followed by waste oils, smuggled fuel and other items [5, 6]. In spite of the law "Fighting against Smuggling" dated 21/3/2007 and numbered 5607, non-standard selling/using activities have still gone on nowadays [5].

It was reported that four types of vegetable oil into nitrogen in an environment with high pressure and high temperature within the study and found the same results for fuel injection [7]. Researchers analyzed the utility of vegetable oils in diesel engines as alternative fuels, their prices and social effects. In short-term studies, vegetable oils were suggested to be convenient, in long-term studies, they were stated to reduce engine performance and life time [8].

There was carbon segregation in the combustion space, especially in the injector nozzle. They informed that problems such as reduction in burning efficiency, solidification in lube oil, and piston and segment adhesion because of decreasing fuel emission occurred [9].

The aim of the present study is to experimentally investigate the effects of using the mineral fuels by partially blending them with standard petroleum diesel fuel. The prepared blends were considered to symbolize the widely used non-standard oil called Oil-NO: 10 in our country that it is illegally used. Therefore the usability of these kinds of fuels was investigated as fuel in diesel engines.

\section{MATERIAL and METHODS}

This study investigated the effects of using the following fuel blends on exhaust emissions in a diesel engine as fuels. 
Test Fuels: D2, K1, K2, K3

D2: Diesel fuel (100\%)

K1: 90\% D2 + 5\% SAE10W + 5\% SAE5W,

K2: 80\% D2 + \%10 SAE10W + 10\% SAE5W,

K3: 70\% D2 + 15\% SAE10W + 15\% SAE5W

In the experiment system, the engine coupled with a hydraulic dynamometer named the BT-140 whit maximum power $50 \mathrm{HP}$. The fuel measuring device that has a capacity of $150 \mathrm{cc}$, which measured fuel waste volumetrically, was used. The system has an automatic control module with speed-rpm, torque-Nm, power-kW digital indicators, adjustment buttons, automatic calibration (measuring) system and hold (freezing values) button. In Figure 1, the schematic diagram of the engine experimental setups was given. Test fuels specifications were given in Table 1, Table 2 and Table 3.

Table 1. Properties of Diesel Fuel (TÜPRAŞ).

\begin{tabular}{|l|l|l|l|l|}
\hline Properties & Unit & Value & Limits & Experimental method \\
\hline Density (@ $\left.15^{\circ} \mathrm{C}\right)$ & $\mathrm{gr} / \mathrm{cm}^{3}$ & $0.820-0.845$ & & $\begin{array}{l}\text { TS 1013 EN ISO 3675 } \\
\text { TS EN ISO 12185 }\end{array}$ \\
\hline Flash point & ${ }^{\circ} \mathrm{C}$ & 55 & Min & TS EN ISO 2719 \\
\hline Sulfur & $\mathrm{mg} / \mathrm{kg}$ & 10 & Max & $\begin{array}{l}\text { TS EN ISO 20846 } \\
\text { TS EN ISO 20884 }\end{array}$ \\
\hline $\begin{array}{l}\text { Kinematic viscosity } \\
\left(@ 40^{\circ} \mathrm{C}\right)\end{array}$ & $\mathrm{cst}$ & $2.0-4.5$ & & TS 1451 EN ISO 3104 \\
\hline Ash content & $\%$ weight & 0.01 & Max & TS EN ISO 6245 \\
\hline Cetane number & & 51 & Min & TS 10317 EN ISO 5165 \\
\hline
\end{tabular}

Table 2. Properties of SAE 5W Mineral Oil

\begin{tabular}{|l|c|c|c|}
\hline Properties & Unit & Value & Experimental method \\
\hline Density $\left(915{ }^{\circ} \mathrm{C}\right)$ & $\mathrm{gr} / \mathrm{cm}^{3}$ & 0.878 & $\begin{array}{c}\text { TS 1013 EN ISO 3675 } \\
15.04 .2002 \\
\text { (ASTM D 1298/99) }\end{array}$ \\
\hline Kinematic viscosity $\left(40{ }^{\circ} \mathrm{C}\right.$ & $\mathrm{mm}^{2} / \mathrm{s}$ & 66.8 & $\begin{array}{c}\text { TS 1451 EN ISO 3104 } \\
/ 07.04 .1999\end{array}$ \\
\hline Flow point & ${ }^{\circ} \mathrm{C}$ & -38 & $\begin{array}{c}\text { TS 1233 ISO 3016 } \\
/ 29.07 .1997 \\
\text { (ASTM D 97/96a) }\end{array}$ \\
\hline Flash point & & & $\begin{array}{c}\text { TS EN ISO 2592 } \\
/ 09.03 .2006 \\
\text { (ASTM D 92/98a) }\end{array}$ \\
\hline
\end{tabular}


Table 3. Properties of SAE 10W Mineral Oil

\begin{tabular}{|c|c|c|c|}
\hline Properties & Unit & Value & Experimental method \\
\hline Density (@15 ㄷ) & $\mathrm{gr} / \mathrm{cm}^{3}$ & 0.875 & $\begin{array}{c}\text { TS } 1013 \text { EN ISO } 3675 \\
15.04 .2002 \\
\text { (ASTM D 1298/99) } \\
\end{array}$ \\
\hline Kinematic viscosity $\left(@ 40^{\circ} \mathrm{C}\right.$ & $\mathrm{mm}^{2} / \mathrm{s}$ & 22.9 & $\begin{array}{c}\text { TS } 1451 \text { EN ISO } 3104 \\
/ 07.04 .1999\end{array}$ \\
\hline Flow point & ${ }^{\circ} \mathrm{C}$ & -33 & $\begin{array}{c}\text { TS } 1233 \text { ISO } 3016 \\
\quad / 29.07 .1997 \\
\text { (ASTM D 97/96a) } \\
\end{array}$ \\
\hline Flash point & ${ }^{\circ} \mathrm{C}$ & 204 & $\begin{array}{c}\text { TS EN ISO } 2592 \\
\quad / 09.03 .2006 \\
\text { (ASTM D 92/98a) }\end{array}$ \\
\hline
\end{tabular}

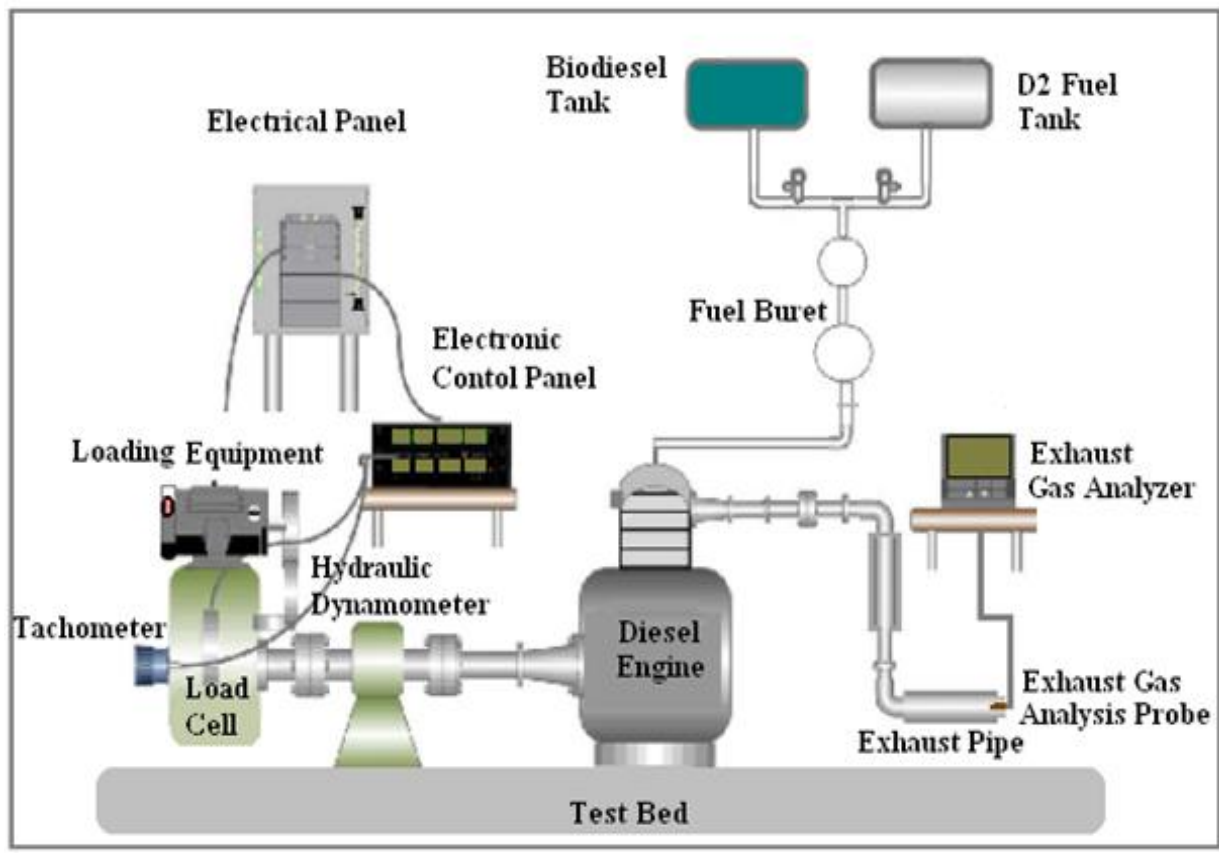

Figure1. Experimental Setup of the Test Installation

Table 4. Technical Properties of Test Engine

\begin{tabular}{|l|l|}
\hline Model & DIESEL 4 LD 820 \\
\hline Cylinder number & 1 \\
\hline Cylinder volume & $817 \mathrm{~cm}^{3}$ \\
\hline Cylinder diameter & $102 \mathrm{~mm}$ \\
\hline Stroke & $100 \mathrm{~mm}$ \\
\hline Compression ratio & $17: 1$ \\
\hline Engine Power & $15(17) \mathrm{BG}$ \\
\hline Maximum torque & $5 \mathrm{~kg}-\mathrm{m} \mathrm{@} 16001 / \mathrm{m}$ \\
\hline Operating system & Optional (starter-arm) \\
\hline
\end{tabular}




\subsection{Procedures of Experiment}

Engine performance and emission experiments were done with a single-cylinder, direct injection, air cooled diesel engine. The test engine specifications were given in Table 4. Before the experiments, the engine fuel pump and the injector calibration were adjusted to catalogue settings. The experiments were carried out in an engine speed ranges of 1000-2000 d/d with the ranges of $200 \mathrm{~d} / \mathrm{d}$ under the 3/4 load conditions. After the engine reached to running temperature, the experiments were done. Before starting a new experiment, the engine was allowed to cool down and stand. Also, the engine was kept on running to consume fuel used in the previous experiment completely until it stopped, and then the fuel tank was filled with new fuel. Hydraulic dynamometer was used for torque and power measurements. The $\mathrm{CO}$ and NOx measurements were performed using the Testo350 exhaust gas analyzer. Each experiment was repeated for five times, their averages were utilized for evaluations. The Testo350 exhaust gas analyzer was used in the experiments. The properties of the Testo350 exhaust gas analyzer were given in Figure 2.

\begin{tabular}{|c|c|c|c|}
\hline \multirow[t]{15}{*}{ testo 350 . Combustion \& Emission Analyzer } & \multicolumn{3}{|c|}{$\begin{array}{l}\text { Measurement ranges and resolution } \\
\text { Analysis box }\end{array}$} \\
\hline & $\begin{array}{l}\text { Measurement } \\
\text { parameter }\end{array}$ & $\begin{array}{l}\text { Measurement } \\
\text { range without } \\
\text { dilution of all } \\
\text { sensors }\end{array}$ & \begin{tabular}{|l} 
Measurement range \\
with dilution of all \\
sensors (option)
\end{tabular} \\
\hline & $\mathrm{O}_{2}$ & $0 . .25 \mathrm{Vol} . \%$ & $\begin{array}{l}\text { The reading does not } \\
\text { appear in the display. }\end{array}$ \\
\hline & $\mathrm{CO}, \mathrm{H}_{2}$-Comp. & $0 . . .10000 \mathrm{ppm}$ & $2500 \ldots 50000 \mathrm{ppm}$ \\
\hline & COlow, $\mathrm{H}_{2}$-comp. & $0 . .500 \mathrm{ppm}$ & $500 \ldots 2500 \mathrm{ppm}$ \\
\hline & NO & 0...4000ppm & $1500 \ldots 20000 \mathrm{ppm}$ \\
\hline & NOlow & $0 . \ldots 300 \mathrm{ppm}$ & $300 \ldots 1500 \mathrm{ppm}$ \\
\hline & $\mathrm{NO}_{2}$ & $0 . .500 \mathrm{ppm}$ & $500 \ldots 2500 \mathrm{ppm}$ \\
\hline & $\overline{\mathrm{SO}_{2}}$ & $0 . .5000 \mathrm{ppm}$ & $500 \ldots 25000 \mathrm{ppm}$ \\
\hline & $\mathrm{H}_{2} \mathrm{~S}$ & $0 . .300 \mathrm{ppm}$ & $200 \ldots 1500 \mathrm{ppm}$ \\
\hline & $\mathrm{CO}_{2}(\mathrm{IR})$ & $0 . .50 \mathrm{Vol} . \%$ & $\begin{array}{l}\text { The reading does not } \\
\text { appear in the display. }\end{array}$ \\
\hline & $\mathrm{HC}^{1,2}$ & \begin{tabular}{|l|} 
Natural gas: \\
$100 \ldots . . .40000 \mathrm{ppm}$
\end{tabular} & $\begin{array}{l}\text { Natural gas: } \\
500 \ldots 800000 \mathrm{ppm}\end{array}$ \\
\hline & & $\begin{array}{l}\text { Propane: } \\
100 . .21000 \mathrm{ppm}\end{array}$ & $\begin{array}{l}\text { Propane: } \\
500 . .42000000 \mathrm{ppm}\end{array}$ \\
\hline & & $\begin{array}{l}\text { Butane: } \\
100 \ldots 18000 \mathrm{ppm}\end{array}$ & $\begin{array}{l}\text { Butane: } \\
500 \ldots 36000000 \mathrm{ppm}\end{array}$ \\
\hline & $\begin{array}{l}1 \text { Detection limit: } 5 \\
2 \text { Strict complianc }\end{array}$ & $\begin{array}{l}\text { om } \\
\text { th the lower explos }\end{array}$ & $\mathrm{n}$ limit is mandatory. \\
\hline
\end{tabular}

Figure 2. Testo350 Exhaust Gas Analyzer

\subsection{EXPERIMENTAL RESULTS}

\subsubsection{CO (Carbon monoxide) Emissions}

In Figure 3, there were changes in carbon monoxide (CO) emission with the engine speed for K1, K2, K3 and D2 fuels.

The main reason of formation of $\mathrm{CO}$ during the combustion is the lack of oxygen. When the excess air coefficient (EAC) was smaller than 1, that is to say, the air rate was low in the fuel-air mixture, the 
combustion process was not complete, it would have low $\mathrm{O}_{2}$ in the environment, all carbons available in the structure of fuel would not be transformed into $\mathrm{CO}_{2}$ and would be ejected from exhaust as $\mathrm{CO}$.

Depending on the engine speed in the fuels of D2 and K1, K2, K3 mixtures, the variances of CO emissions were seen in Figure 3. As clearly seen in Figure 3, the CO emissions were higher than the D2 fuel in the $\mathrm{K} 1, \mathrm{~K} 2$ and $\mathrm{K} 3$ mixtures.

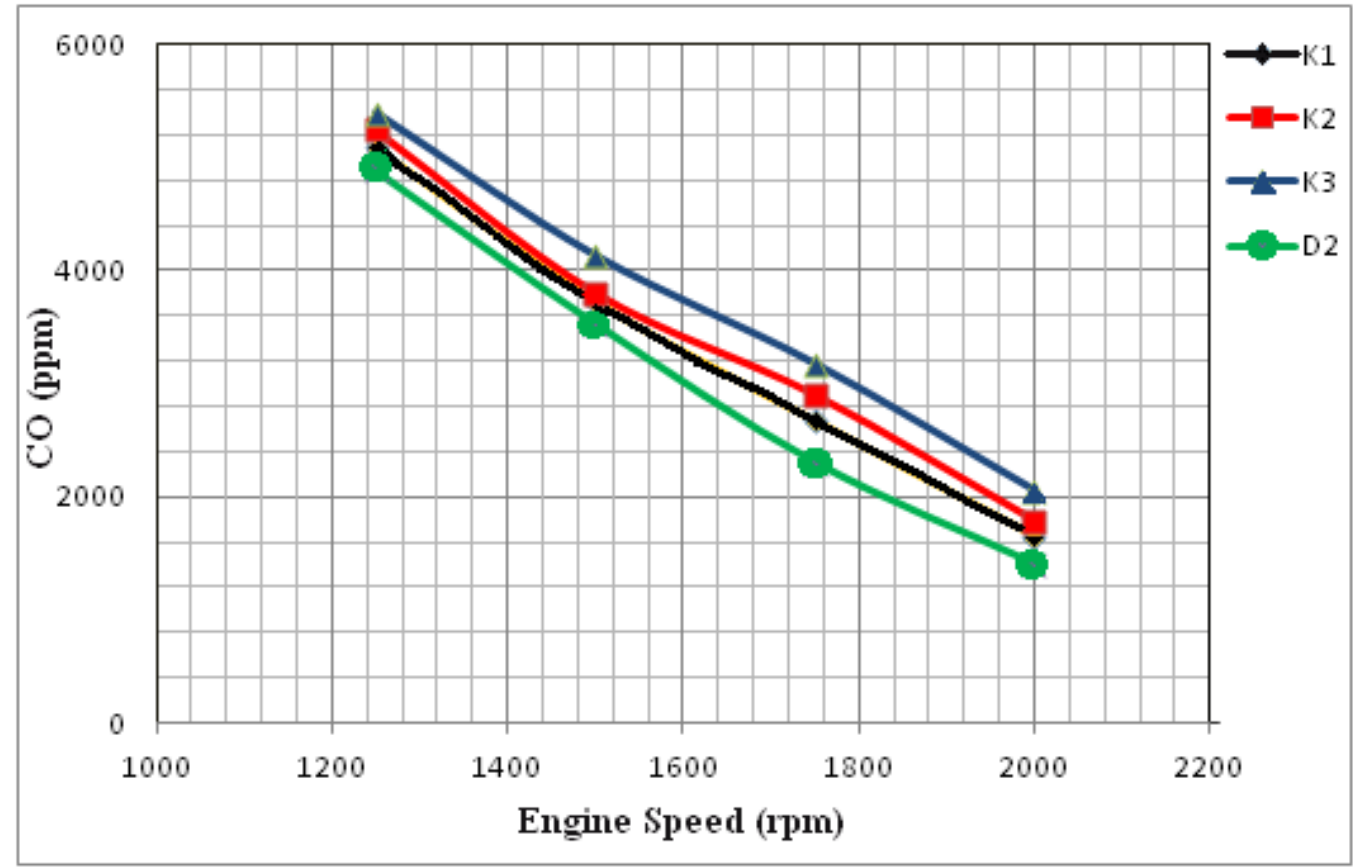

Figure 3. Variation of $\mathrm{CO}$ emissions for test fuels with engine speed.

In mineral oils, without depending on the EAC, since the oxygen rate was low in the body of fuel, the carbons could not find enough oxygen and transform into CO. That's why; the $\mathrm{CO}$ emissions were more than the D2 fuel in the usage of mineral oil.

The reason for high $\mathrm{CO}$ emissions at low speeds can be explained that the cylinder walls were cooler at low engine speeds rather than high speeds, the pressure of combustion space was low, the air motion was insufficient and the combustion remains in-complete.

\subsubsection{NOx (Nitrogen Oxide) Emissions}

In Figure 4, the variation of nitrogen oxide (NOx) emission with the engine speed for K1, K2, K3 and D2 fuels are presented. 


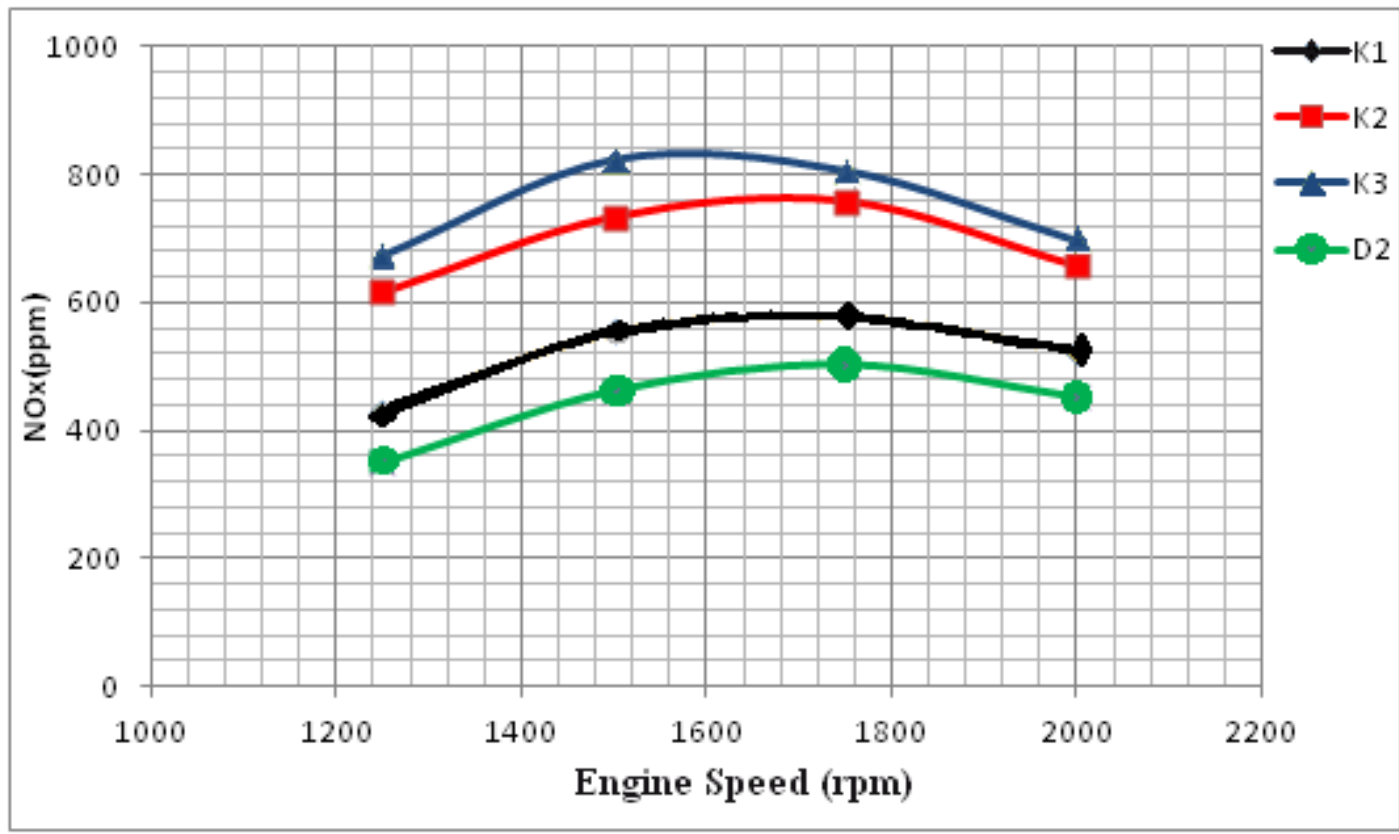

Figure4. Variation of NOx Emissions for Test Fuels with Engine Speed.

Under the normal conditions, nitrogen in air does not enter in the combustion reactions. But when nitrogen in air reacted to oxygen because of high temperatures in the combustion space during combustion, nitrogen oxides occurred. The temperature in the cylinder considerably affected the formation of nitrogen oxides and when temperature increased, the formation of the nitrogen oxides rapidly got high as well.

Another parameter which affected the occurrence of nitrogen oxide was EAC. When the EAC was bigger than 1 , the oxygen rate increases and the formation of nitrogen oxide increase as well.

As can be seen at Figure, depending on the engine speed, firstly, the NOx emissions normally increased for theK1, K2, K3 and D2 mixtures, and then they decreased.

\subsubsection{HC (Hydrocarbon) Emissions}

At Figure 5, there were variance graphs of hydrocarbon (HC) emission with the revolutions per minute for $\mathrm{K} 1, \mathrm{~K} 2, \mathrm{~K} 3$ and D2 fuels. 


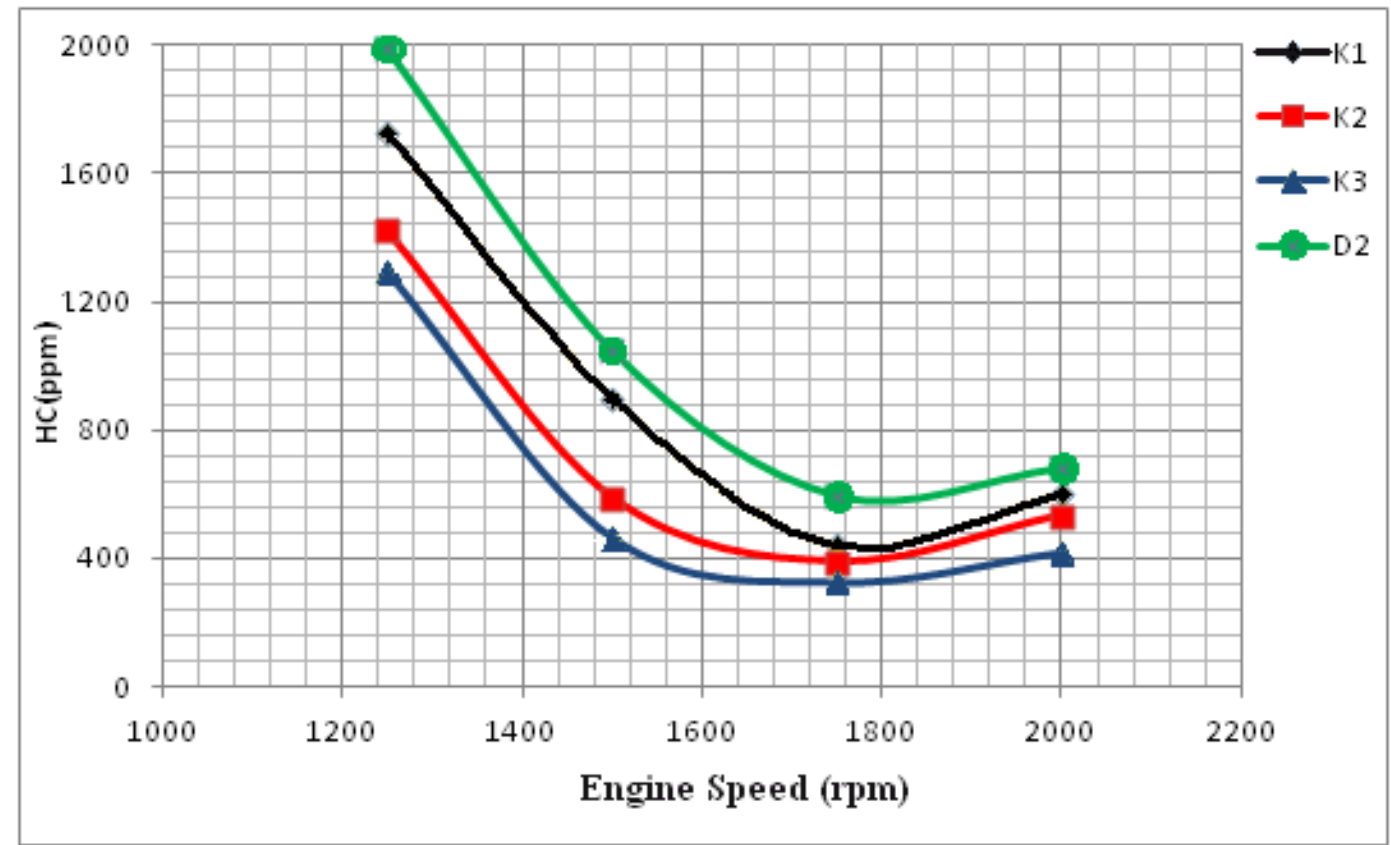

Figure 5. Variation of $\mathrm{HC}$ emissions for test fuels with engine speed.

$\mathrm{HC}$ emission in diesel engines resulted from the poor combustion of fuels. Large structures of hydrocarbon molecules were splitted with the effect of temperature and divided into smaller hydrocarbons. As a result of the reaction of hydrocarbons to oxygen, combustion happened. Highly rapid combustion reaction and insufficient oxygen caused some small hydrocarbon combinations not to complete combustion reaction. After fuel was mixed with air during the ignition delay, some parts may be poor or rich, some parts may be burned. As seen in Figure 5, HC formation was decreased continuously with increase in the engine speed due to the improved air movements in the combustion chamber that leads to more complete combustion.

\subsection{4. $\mathrm{SO}_{2}$ (Sulfur Dioxide) Emissions}

In Figure 6, there were variation of sulfur dioxide $\left(\mathrm{SO}_{2}\right)$ emission with the engine speed for $\mathrm{K} 1, \mathrm{~K} 2, \mathrm{~K} 3$ and D2 fuels.

Sulfur dioxide $\left(\mathrm{SO}_{2}\right)$ was a colorless, nasal burner gas. It was an emission resulting from sulfur content in fuel. When it reacted to water vapor, it caused the formation of sulfur dioxide. This also destroys engine materials. Then $\mathrm{SO}_{2}$ involved in atmosphere fell with rain as acid rains in the earth again. Its effects became stronger due to particulates in exhaust gases; it gave rise to damages in respiratory tracts and burning in eyes. As can be seen the figure, the $\mathrm{SO} 2$ emissions of the blend fuels were considerably higher than those of diesel fuel. It can be attributed to the sulfur content of the non-standard oils. These important findings show that these kinds of fuels are not suitable for used in diesel engines, as fuels. 


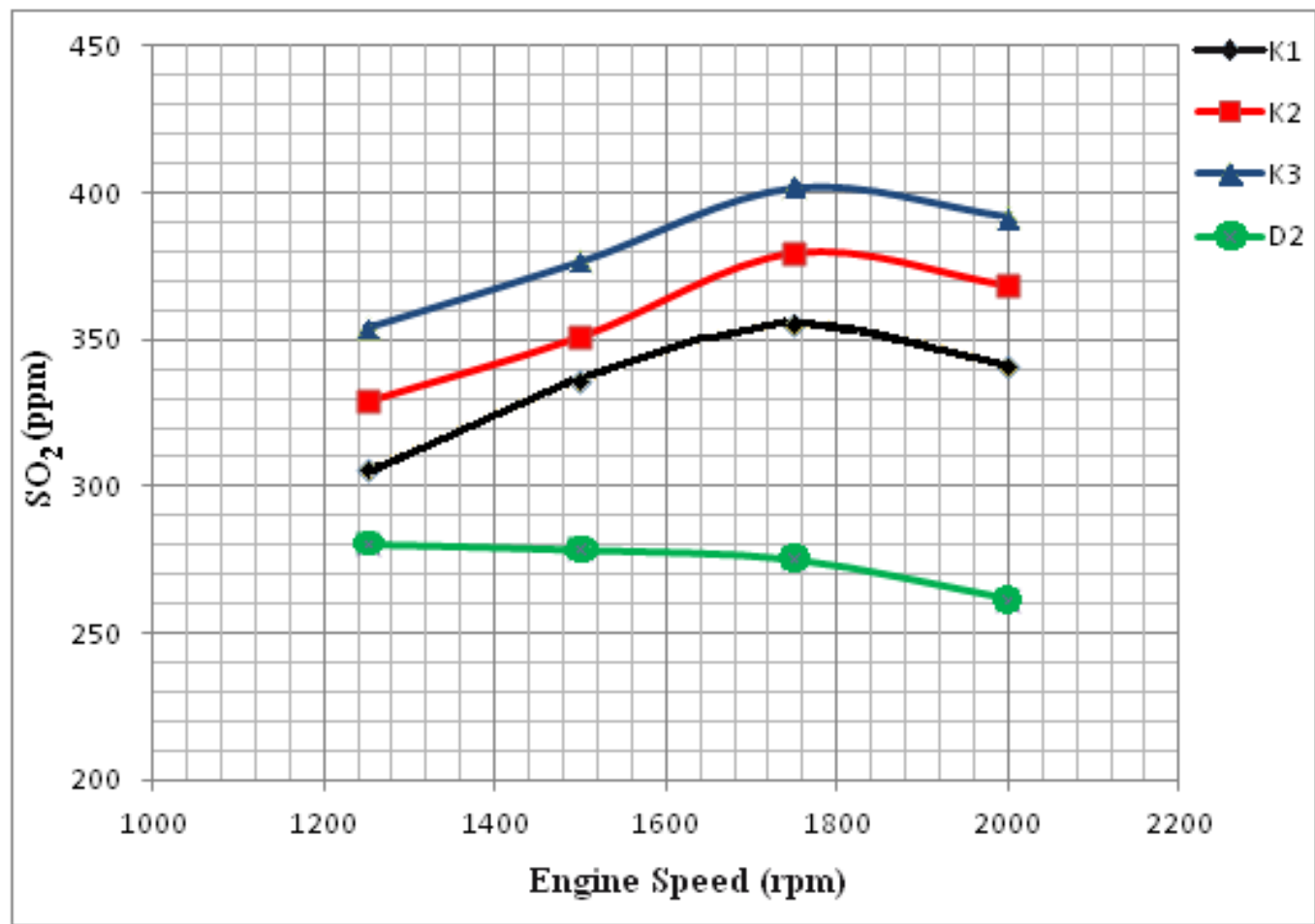

Figure 6. Variation of $\mathrm{SO}_{2}$ emissions for test fuels with engine speed.

\section{CONCLUSION AND EVALUATION}

In this paper, mineral oil-diesel fuel blends were used as fuel in a diesel engine in order to determine exhaust emissions of a diesel engine, thus its effects on environmental pollution. Diesel fuel, Oil NO: 10 and their mixture at certain rates were utilized in a single-cylinder diesel engine. Fuels used in the experiment were similar to fuels considered to be generally used in trucks and coaches through illegal ways on market. As opposed to these fuels with diesel fuel, they did not show any differences from diesel fuel in terms of engine performance. Since they provided similar performance to diesel fuel at low speeds, even if it seemed to be more economical in a long term, it is considered that they can make great effects like giving harms to cylinder in engine and piston in combustion space due to viscosity and density differences. Since it created excess heat resulting from burning in cylinder, it is suggested that the cooling system may be insufficient. These results in that engine lifetime may reduce. Also, the values from exhaust emission measurements indicated that the $\mathrm{CO}$ amount was more than the D2 fuel. When evaluated in the components of $\mathrm{SO}_{2}$, all of the mixtures presented more $\mathrm{SO}_{2}$ emission than the $\mathrm{D} 2$ fuel at all engine speeds. Within the research focused on the mixture fuels, the NOx values were higher than the values of D2 fuel under all engine speeds and operating conditions. Another indicator was that the fuel mixtures caused more heat in the combustion space, so it gave rise to any decrease in $\mathrm{HC}$ emissions rather than the D2 fuel. It is considered that these oils produced for lubricating but used for fuel and permanent warm parts in engine for a long time may give damage to engine materials, they may cause fire in engine when the cooling system breaks down. Furthermore, considering the $\mathrm{CO}, \mathrm{NOx}$ and $\mathrm{SO}_{2}$ values, these fuel mixtures are regarded to be insufficient to prefer since it may lead to harmful effects on environment. 


\section{REFERENCES}

[1] Nwafor O.M.I., Emission Characteristics of Diesel Engine Running on Vegetable Oil the With Elevated Fuel Inlet Temperature, (2004), Biomas and Bioenergy 27: 507-511

[2] Akgün, G., Bayındır, H., Aydın, H. and Düz, Z., A Study on the Determination of Biodiesel Production and Technical Values from Animal Fat. V. Renewable Energy Sources Symposium. Diyarbakır/Turkey. InTurkish. (2009).

[3] Sugözü İ., Aksoy F., Baydır A. Ş. The Effect of the Use of Sunflower Methyl Esther on Engine Performance and Emissions in a Diesel Engine, Electronic Journal of Machinery Technology Vol: 6, (2009). No: 2, 49-56. In Turkish.

[4] Özer S., Vural E., Özdalyan B., Effects of Canola Oil Methyl Ester - Diesel Fuel Mixtures on Engine Performance and Exhaust Emissions in Diesel Engines, Electronic Journal of Vehicle Technology (TATED), (2011), Volume: 3,No: 1, 9-18. In Turkish.

[5] PETDER, (der2008). Petroleum Industry Association, Report, April, Ankara. In Turkish.

[6] Saydut, S. Erdogan, A.B. Kafadar, C. Kaya, F. Aydin, C. Hamamci. Process optimization for production of biodiesel from hazelnut oil, sunflower oil and their hybrid feedstock, Fuel, 183, 512-517 (2016).

[7] Ryon, T.W., Bagby, M.O., Identification of Chemical Changes Occurring During The Transient Injection of Selected Vegetable Oils, SAE Special Pub1958, (1993),

[8] Lowry, J.P.A., Alternative Fuels for Automotive and Stationary Engines in Developing Countries, Fuel for Automotive and Industrial Diesel Engines. Institution of Mechanical Engineers, Mechanical Engineering Publication, (1990),

[9] Ziejewski, M., Kaufman, K.R., Laboratory Endurance Test of Sunflower Oil Blend in Diesel Engine. JAOCS, (1983), vol.60, no: 8. 